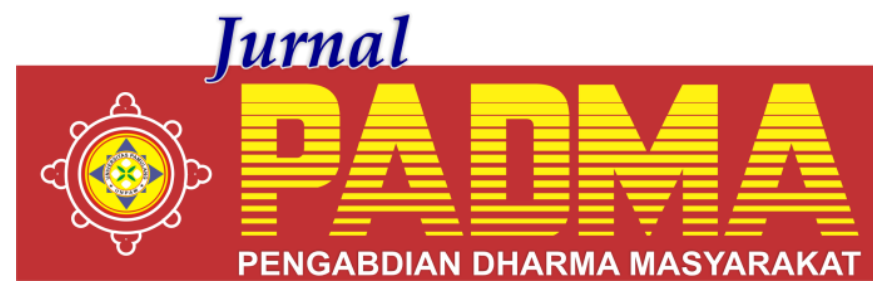

VOLUME I, NOMOR 1, JANUARI 2021

\title{
PELATIHAN DASAR KEPEMIMPINAN TAMAN BELAJAR KREATIF MEKARSARI
}

\author{
${ }^{1 *}$ Arif Hidayat, ${ }^{2}$ Edian Fahmy, ${ }^{3}$ Dian Rostikawati, ${ }^{4}$ Waluyo Jati, ${ }^{5 Z a e n a l ~ M u t t a q i n ~ A b d i ~}$ \\ Universitas Pamulang, Tangerang Selatan, Banten, Indonesia \\ *dosen02519@unpam.ac.id
}

\begin{abstract}
Abstrak
Tujuan diselenggarakannya kegiatan Pengabdian Kepada Masyarakat ini adalah untuk menumbuhkan jiwa kepemimpinan pada Taman Belajar Mekarsari Bogor yang sesuai dengan perkembangan jaman yang actual dan terkini. Selain itu dapat menggerakkan para anggota karang taruna untuk dapat mengembangkan jiwa kepemimpinan. Metode pelaksanaan menggunakan teknik penyuluhan dengan menggunakan proyektor, seminar, diskusi forum dan tanya jawab. Hasil kegiatan pengabdian ini dapat membuka wawasan dari para anggota karang taruna, sehingga tidak hanya memberikan tambahan pengetahuan tetapi juga dapat diterapkan khususnya dalam menerapkan kemampuan berorganisasi. Selain itu diharapkan juga dapat membantu dan meningkatkan kepemimpinan mereka dengan pendekatan terkini atau milenial.
\end{abstract}

Kata Kunci: Kepemimpinan

The purpose of holding this Community Service activity is to foster a spirit of leadership in the Bogor Mekarsari Learning Park which is in accordance with the actual and current developments. In addition, it can move members of the youth organization to be able to develop a spirit of leadership. The method of implementation uses extension techniques using projectors, seminars, forum discussions and frequently asked questions. The results of this service activity can open insights from members of the youth organization, so that it not only provides additional knowledge but can also be applied, especially in applying organizational skills. In addition, it is hoped that they can help and improve their leadership with the latest or millennial approaches.

Keywords: Leadership

\section{PENDAHULUAN}

Kepemimpinan menjadi salah satu faktor penting bagi keberhasilan sebuah organisasi. Untuk itu, ada beberapa sikap kepemimpinan dalam organisasi yang perlu diterapkan oleh seorang pemimpin, diantaranya:

Menjalin kedekatan dengan anak buah. Kepemimpinan dalam organisasi akan menjadi lebih efektif jika seorang pemimpin telah mendapat respek dari anak buah. Hal ini bisa dibangun dengan menjalin kedekatan dengan mereka, sehingga mereka akan percaya dan mau mengikuti arahan Pemimpin.

Memberikan semangat dan motivasi. Kepemimpinan dalam organisasi bukan melulu soal pangkat dan jabatan, tetapi kepemimpinan adalah bagaimana seorang pemimpin dapat memberikan semangat dan motivasi, bahkan untuk setiap hal kecil dari pekerjaan yang anak buah pimpinan lakukan.

Memberikan kepercayaan dan tanggung jawab. Kepemimpinan dalam organisasi adalah tentang kepercayaan. Berikan anak buah Pemimpin kepercayaan dan tanggung jawab yang lebih dalam melakukan tugas mereka.

Jika ada hal yang tidak sejalan, jangan langsung menghakimi. Berikanlah feedback agar ke depannya mereka tidak takut salah dalam mengambil sebuah keputusan.

Agar seseorang dapat menjadi pemimpin yang baik, tentunya akan dibutuhkan pengalaman panjang selama bertahun-tahun di dalam sebuah organisasi. Namun, hal tersebut bukan lagi menjadi masalah dengan adanya jasa pelatihan kepemimpinan (leadership training) dan konsultasi untuk pengembangan SDM dan organisasi. 
Identifikasi masalah yang ditemukan di lapangan adalah masih kurangnya pemahaman dan pengetahuan para remaja khususnya Karang Taruna dalam hal mengatur diri dan membuat perencanaan kerja serta mengarahkan diri dalam membuat keputusan. Hal itu dikarenakan para anggota mayoritas masih belum memiliki pemahaman dan sikap dalam berorganisasi yang baik. Sehingga diperlukan Pelatihan Dasar Kepemimpinan untuk membentuk sikap dan mental mereka dalam berorganisasi.

Materi yang diberikan oleh pemateri berkaitan dengan kepemimpinan berupa penyuluhan mengenai karakter pemimpin yang benar. Dilanjutkan dengan sesi komunikasi yang meliputi penyuluhan mengenai cara-cara berkomunikasi yang benar sebagai layaknya seorang pemimpin. Selain itu, ada juga sesi problem solving yaitu mengenai caracara seorang pemimpin memecahkan masalah secara efektif dan benar.

Dan kegiatan ditutup dengan pembagian sertifikat oleh panitia kepada peserta Latihan Dasar Kepemimpinan.

Kegiatan pengabdian kepada masyarakat dari tim dosen dan mahasiswa Universitas Pamulang hadir di pada Taman Belajar Mekarsari Rumpin Bogor, serta berbagi pengetahuan dan wawasan dengan bentuk penyuluhan yang menggunakan teknik group discussion untuk lebih dapat mengasah jiwa kepemimpinan pada diri anggota. Penyuluhan yang bertujuan menumbuhkan jiwa kepemimpinan pada anggota Taman belajar ini ini semata-mata untuk membangun mental positif dan optimisme, terutama menanamkan rasa percaya kepada anggota dan semangat memotivasi dengan pendekatan terkini yang tentunya akan menjadi modal yang kuat dalam menciptakan program-program di masyarakat yang bagus dan kekinian.

Tim pengusul pengabdian kepada masyarakat berharap respon dan antusias civitas akademika, khususnya mahasiswa pada Taman Belajar Mekarsari Rumpin Bogor dalam membentuk jiwa kepemimpina. Sehingga kegiatan pengabdian kepada masyarakat tidak hanya berhenti pada kegiatan penyuluhan ini tetapi dapat berkelanjutan sesuai kebutuhan penyusunan program kerja taman belajar, terutama yang berkaitan dengan pengembangan karakter sebagai bentuk kepedulian terhadap organisasi dan pencapaian kinerja di masa depan.

\section{METODE}

1. Kedisiplinan

Kedisiplinan dibangun untuk membuat peserta paham terhadap norma dan stPemimpinr etika yang ada. Apabila dapat memahaminya maka akan timbul tindakan yang sesuai. Dengan begitu seseorang dapat lebih sistematis dan teratur. Kedisiplinan juga memberikan pemahaman akan pentingnya nilai waktu yang membuat seseorang menghargai dan memanfaatkannya sebaik mungkin. Halhal tersebut akan menghasilkan ketentraman dan juga rasa saling percaya satu sama lain dalam organisasi.

2. Rasa solidaritas

Melalui kegiatan ini, seluruh peserta diuji rasa solidaritasnya. Bagaimana setiap individu harus rela berkorban demi kelompoknya, bagaimana mengenyampingkan ego, dan lainnya. Jika solidaritas terbentuk maka hubungan interpersonal pun akan terjadi dimana rasa kepedulian satu sama lain akan timbul, memahami kelebihan dan kekurangan, dan membantu disaat senang maupun duka. Dengan membangun solidaritas suatu kelompok akan menjadi kompak sehingga dapat mencapai tujuan dan keselarasan bersama.

3. Bertanggung jawab

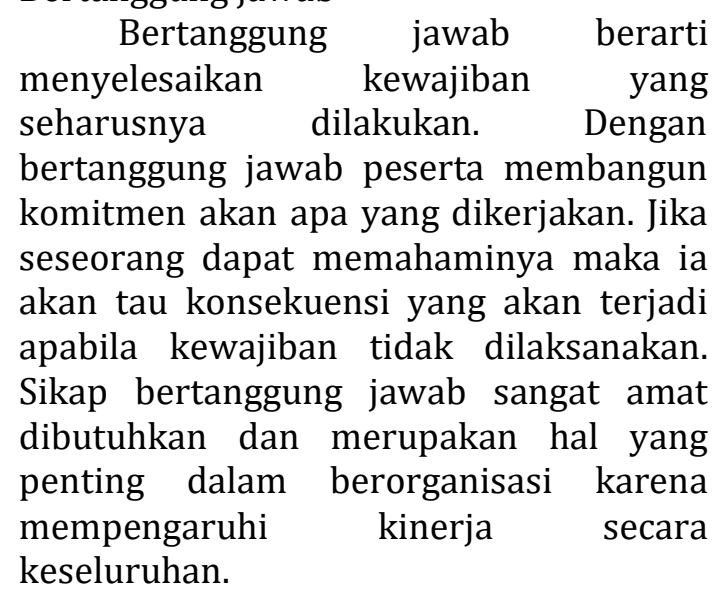

\section{HASIL DAN PEMBAHASAN}

Kegiatan Pengabdian Kepada Masyarakat ini berkaitan erat dengan upaya 
pembinaan dan pengembangan sumber daya manusia pada Karang Taruna Mekarsari. Pembinaan dan pengembangan mengenai sumber daya manusia diberikan dalam kemasan penyuluhan agar lebih mudah dipahami. Dengan pendekatan persuasif diharapkan para remaja lebih terbuka untuk ,menyampaikan permasalahan yang dihadapi atau menyampaikan kebutuhan mereka terkait dengan pengembangan diri. Artinya, pelaksanaan pengabdian kepada masyarakat dengan melakukan penyuluhan kepada anggota Karang Taruna Mekarsari Rumpin yang beranggotakan 30 orang dari berbagai latar belakang social dan berbagai jenjang pendidikan. Dengan penyuluhan tentang manajemen sumber daya manusia di kalangan Karang Taruna Mekarsari Kecamatan Rumpin Kabupaten Bogor Jawa Barat diharapkan dapat memberikan wawasan kepada anggota yang nantinya dapat diimplementasikan oleh anggota dan ditularkan ke masyarakat luas.

Kegiatan Pengabdian Kepada

Masyarakat ini berkaitan erat menumbuhkan jiwa kepemimpinan pada pada Taman Belajar Mekarsari Rumpin Bogor yang sesuai dengan perkembangan jaman yang actual dan terkini. Melalui kegiatan LDK ada penambahan wawasan dalam berpikir, bersikap dan bertingkah laku. Fokus Kegiatan Latihan Dasar Kepemimpinan ini yakni pemberian bekal kepemimpinan dan manajemen organisasi kepada taman belajar dalam bentuk penyuluhan mental kepemimpinan, pembinaan kepemimpinan, kekompakan, tanggung jawab dalam menjalankan kegiatan organisasi. Era Milenial diwarnai dengan perubahanperubahan menuju kearah perbaikan. Pembelajaran yang didapat dalam kegiatan LDK ini yakni:

Belajar Tentang Organisasi. Taman belajar diajarkan berbagai kemungkinan yang akan dihadapi seseorang ketika memimpin suatu organisasi. Selain itu, pembelajaran mengenai bagaimana pembuatan proposal hingga pendataan yang baik dalam suatu organisasi, pembelaharan mengenai bagaimana cara berkomunikasi secara ideal dalam suatu organisasi.

Pembagian kelompok yang dilakukan melatih setiap anggota taman belajar melakukan komunikasi secara efektif. Para anggota menjalin kerjasama dalam menyelesaikan tugas yang diberikan.

Melatih Keprcayaan Diri. Pemberian materi LDK yang disampaikan sudah membantu untuk menghadapi rasa takut gagal yang menghantui pikiran. Oleh fasilitator LDK, peserta diminta berinteraksi dan menjawab beberapa hal. Kegiatan ini mendorong peserta aktif sehingga berani berbicara dan secara tidak langsung memberikan pembiasaan kepada para peserta agar lebih percaya diri.

Belajar Menyelesaikan Masalah. Peserta mengikuti beberapa permainan yang memiliki fungsi melatih cara berpikir untuk menyelesaikan masalah. Permainan yang diberikan berbeda-beda, ada yang benarbenar mudah dan ada pula yang pastinya sulit. Namun melalui permainan ini para peserta berusaha mencari solusi agar mampu menyelesaikan permainan tersebut. Secara tidak langsung telah melatih para peserta agar mampu menyelesaikan suatu permasalahan.

Meningkatkan Kemampuan Berpikir. Kegiatan LDK melatih penggunaan logika untuk melihat suatu masalah. Para fasilitator mengarahkan untuk melihat segala kemungkinan yang bisa ambil dengan menggunakan pemikiran. Peserta dilatih agar dapat berpikir dalam kondisi apapun dengan sekreatif mungkin. Dengan kegiatan ini, para peserta akan mampu mencari solusi dengan pemikirannya masing-masing sehingga membentu pola pikir jauh ke depan dan bisa mengantisipasi permasalahan.

Mengasah People Skill. People Skill adalah keterampilan dalam berhadapan dengan orang lain dengan cara yang tepat sehingga lawan bicara akan selalu nyaman saat berhadapan dengan diri kita Keterampilan ini didapat dari tujuan masingmasing permainan kepemimpinan diberikan dalam LDK ini. Melalui kegiatan ini para peserta akan mampu mengerti bagaimana menghadapi orang lain tanpa membuat risih atau terganggu atas keberadaan. Selain itu, dapat membaca perilaku orang lain saat berbicara atau berhadapan.

Pemuda mempunya peran yang sangat enting dalam pembangunan sutau bangsa. Seperti yang sudah kita ketahui bahwa pada masa kolonial, para pemuda ikut berperan dalam memperjuangkan kemerdekaan 
seperti Budi Outomo, Soekarno, M. Hatta dan tokoh-tokoh muda lainnya. Namun, pada era milenial ini peran pemuda saat ini sudah mengalami penurunan fungsi dan mengalami masalah etika dan moral. Permasalahan tersebut tidak terlepas dari globalisasi dan modernisasi yang memberikan banyak akses informasi sehingga generasi muda yang masih dalam masa peralihan akan mengalami kebingungan dalam menghadapi permasalahan yang mereka hadapi.

Peran dan partisipasi para pemuda sangatlah penting bagi kesejahteraan masyarakat, sehingga sudah menjadi suatu kepastian bahwa setiap negara selalu berusaha untuk membangun pengetahuan, keterampilan, dan karakter pemuda. Dalam mewujudkan hal tersebut, para generasi muda perlu diberikan wadah untuk mengekspresikan diri mereka. Salah satu tempat untuk menyalurkan potensi pemuda adalah dalam organisasi kepemudaan. Di Indonesia, telah banyak terbentuk organisasi kepemudaan salah satunya pada tingkat desa adalah taman belajar. Taman belajar merupakan suatu organisasi yang terdiri dari anggota masyarakat melalui kesadaran dan tangguang jawabnya untuk mengembangkan dan membangun kesejahteraan masyarakat utamany generasi pemuda di desa masyarakat tersebut.

\section{PENUTUP}

Hasil kegiatan PKM di Desa Mekarsari Rumpin Bogor berjalan dengan lancar. Para peserta dari Karang Taruna Mekarsari terlihat fokus dan antusias mengikuti penyuluhan pengembangan manajemen sumber daya manusia. Kegiatan ini dapat meningkatkan soft skill yang dibutuhkan dalam perannya sebagai generasi muda yang berkiprah sebagai anggota organisasi karang taruna. Para perserta mendapatkan pengalaman dan support untuk mengembangkan potensinya

Pelaksanaan kegiatan pengabdian masyarakat oleh lembaga penelitian dan pengembangan masyarakat (LPPM) Universitas Pamulang yang dilakukan oleh dosen-dosen program studi Pendidikan Ekonomi dan Manajemen telah berjalan dengan lancar dan mendapat sambutan hangat dari tempat pelaksanaan kegiatan ini yaitu para anggota pada Taman Belajar Mekarsari Rumpin Bogor.

Dengan ada kegiatan ini menjadikan para anggota taman belajar di lingkungan Kelurahan Pamulang Barat dapat memahami pentingnya pelatihan dasar kepemimpinan milenial

\section{DAFTAR PUSTAKA}

Arikunto, Suharsimi, 2002. Prosedur Penelitian: Suatu Pendekatan Praktek. Jakarta: Rineka Cipta. As?ad, Moh., 1998. Psikologi Industri. Yogyakarta: Liberty.

Dessler, Gary, 1992. Manajemen Personalia. Jakarta: Erlangga. Fatherius, Achmad, 1997. Hubungan Lingkungan Internal dan Eksternal terhadap Produktivitas Karyawan Perusahaan Tekstil di PT. Pabrik Cambries Primissima. Yogyakarta. Yogyakarta: Pascasarjana UGM.

Gibson, James L., 1987. Kepemimpinan Organisasi: Perilaku dan Struktur. Jakarta: Erlangga. Ghozali, Imam, 2001. Aplikasi Analisis Multivariate dengan Program SPSS. Semarang: Universitas Diponegoro Gujarati, Damodar, 1995. Basic Econometrics, ed. 3. Boston

Hermawati, R., Sugiyarti, L., Handayani, R., Sunarsi, D., Alfiah, S., \& Maddinsyah, A. (2020). The Effect of Trilogy Leadership Style and Organization Culture on School Performance: Evidence form Indonesian Senior High School. PalArch's Journal of Archaeology of Egypt/Egyptology, 17(6), 8512-8537.

McGraw Hill. Hasibuan, Malayu S. P., 2001. Manajemen Sumber Daya Manusia. Jakarta: Bumi Aksara. Kartono, Kartini, 1998. Pemimpin dan

Kepemimpinan: Apakah Pemimpin Abnormal Itu? Jakarta: RajaGrafindo Persada

Noviyanti, I., Hayati, F. A., Nufus, K., Maduningtias, L., Rostikawati, D., Sunarsi, D., \& Effendy, A. A. (2020). Did Virtual Transformational Leadership Style Influence Schools Performance? Answer form Indonesian Senior High Schools. PalArch's Journal of Archaeology of Egypt/Egyptology, 17(6),8438-8461. 